\title{
A New Isoflavone from Smilax glabra
}

\author{
Yijun Yi*a , Zhengzhong Cao ${ }^{a}$, Dalong Yang ${ }^{a}$, Yuan Cao ${ }^{a}$, Yongping Wu ${ }^{a}$, Shouxun Zhao \\ ${ }^{a}$ Department of Natural Product Chemistry, Jiangsu Province Institute of Materia Medica, Nanjing 210009, P. R. China. \\ Tel. +86253614065, Fax. +8625 3614090, Email zzcao@pub.jlonline.com \\ ${ }^{\mathrm{b}}$ China Pharmaceutical University, Nanjing 210009, P. R. China
}

Received: 25 February 1998 / Accepted: 10 March 1998 / Published: 15 May 1998

\begin{abstract}
A new isoflavone, 7,6'-dihydroxy-3'-methoxyisoflavone, has been isolated from the roots of Smilax glabra. The structure was determined by 2D-NMR techniques.
\end{abstract}

Keywords: Smilax glabra, isoflavone, 7,6'-dihydroxy-3'-methoxylisoflavone

\section{Introduction}

Smilax glabra Roxb. (Liliaceae), which was called "Tu $\mathrm{Fu}$ Ling", is widely distributed in east and southwest regions of China. In traditional chinese medicine, the rhizome of $S$. glabra has been used clinically to prevent leptospirosis, and to treat syphilis, acute bacterial dysentery, acute and chronic nephritis, etc. [1].

Several chemical constituents have been isolated from this plant in our laboratory[2-5]. In the present work, silica gel chromatography of the EtOAc part of the EtOH extracts of the roots of $S$. glabra has led to the isolation of a new isoflavone. It was elucidated as 7,6'-dihydroxy-3'methoxy-isoflavone (1) based on MS and ${ }^{1} \mathrm{H}-$ and ${ }^{13} \mathrm{C}$ NMR spectroscopy, including ${ }^{1} \mathrm{H}^{-1} \mathrm{H}$ COSY, COLOC and
NOEDS techniques. In this paper we report the structural elucidation of the new isoflavone $\mathbf{1}$.<smiles>COc1ccc(O)c(-c2coc3cc(O)ccc3c2=O)c1</smiles>

Formula 1

\footnotetext{
* To whom correspondence should be addressed. Present address: Department of Natural Product Chemistry, Jiangsu Province Institute of Materia Medica, Nanjing 210009 P.R.China. Tel. +86 2533614065 , Fax. +86 25 3614090, Email yihuco@public1.ptt.js.cn
}

(C) 1998 MDPI. All rights reserved. Molecules http://www.mdpi.org/molecules/ 


\section{Results and Discussions}

Compound 1, pale yellow needles (acetone), mp 250 252. Gave positive $\mathrm{Mg}-\mathrm{HCl}$ (reddish) and $\mathrm{FeCl}_{3}$ (greenish-brown) colour tests. In the ${ }^{1} \mathrm{H}-\mathrm{NMR}$ spectrum, the singlet was observed at $\delta 7.7(\mathrm{~s}, 1 \mathrm{H})$. In the UV spectrum, the maximum absorption was at $255 \mathrm{~nm}$. Thus, 1 was deduced to be an isoflavone which was also confirmed by the ${ }^{13} \mathrm{C}$-NMR(DEPT) spectra (see Table 1 ).

The EI-MS of 1 exhibited [M] ${ }^{+}$at $\mathrm{m} / \mathrm{z} 284.0672$ for $\mathrm{C}_{16} \mathrm{H}_{12} \mathrm{O}_{5}$ (Calc. 284.0679) which is in accord with an isoflavone containing two hydroxyl groups and a methoxy group. In order to determine the substituted positions, 2DNMR techniques were used. The COLOC spectrum showed a correlation between $\mathrm{H}-2$ and $\mathrm{C}-9, \mathrm{H}-8$ and $\mathrm{C}-9$, C-7. This correlation confirmed that the hydroxyl group in ring $\mathrm{A}$ was at the $\mathrm{C}-7$ position.

Furthermore, the ion $\mathrm{m} / \mathrm{z} 148$ observed in the EIMS was derived from ring $\mathrm{B}$ and suggested that it carried one hydroxyl group and a methoxy group. In the ${ }^{1} \mathrm{H}-\mathrm{NMR}$, there are two groups of peaks of $\mathrm{B}$ ring, $\delta 6.5(1 \mathrm{H}, \mathrm{d}$, $\mathrm{J}=2 \mathrm{~Hz}$ ) and $\delta 6.3(2 \mathrm{H}, \mathrm{m})$. The position of methoxy group at
C-3' was deduced from the NOEDS of 1 that showed an enhancement of the peaks of methoxy and $\mathrm{H}-2$ on irradiation of $\mathrm{H}-2$ '. In the ${ }^{1} \mathrm{H}-{ }^{1} \mathrm{H}-\mathrm{COSY}$, the correlations of $\mathrm{H}-2$ and $\mathrm{H}-2$ ', $\mathrm{H}-2$ and $\mathrm{MeO}$ were shown. The position of the hydroxyl group at C-6' was confirmed by ${ }^{1} \mathrm{H}^{-}{ }^{1} \mathrm{H}-$ COSY which displayed the correlation between methoxy and $\mathrm{H}-4$ '.<smiles>COc1ccc(O)c(-c2coc3cc(O)ccc3c2=O)c1</smiles>

Figure 1. Atomic numbering of compound 1.

The structure of $\mathbf{1}$ was fully in accordance with its NMR spectra including COLOC, DEPT and ${ }^{1} \mathrm{H}-{ }^{1} \mathrm{H}-\mathrm{COSY}$ spectra. Thus, 1 was deduced to be 7,6'-dihydroxy, 3'methoxy isoflavone.

Table 1. Correlated ${ }^{13} \mathrm{C}$ - and ${ }^{1} \mathrm{H}$-Data and COSY for compound $\mathbf{1}$.

\begin{tabular}{|c|c|c|c|c|c|c|c|}
\hline Atomic no. & $\varepsilon_{\mathrm{C}}$ & $\mathrm{CHn}$ & $\varepsilon_{\mathrm{H}}$ & Mult. & $J(\mathrm{~Hz})$ & $\operatorname{COLOC}(\mathrm{C}$ to $\mathrm{H})$ & ${ }^{1} \mathrm{H}-{ }^{1} \mathrm{H} \mathrm{COSY}$ \\
\hline 2 & 153.4 & $\mathrm{CH}$ & 7.7 & $\mathrm{~s}$ & & $\mathrm{H}-2$ & $\mathrm{H}-2^{\prime}, \mathrm{CH}_{3}$ \\
\hline 3 & 125.0 & $\mathrm{C}$ & & & & H-2,H-2' & \\
\hline 4 & 175.0 & $\mathrm{C}$ & & & & $\mathrm{H}-5, \mathrm{H}-2, \mathrm{H}-8$ & \\
\hline 5 & 127.6 & $\mathrm{CH}$ & 7.4 & $\mathrm{~d}$ & 8.7 & H-5 & H-6 \\
\hline 6 & 115.5 & $\mathrm{CH}$ & 6.3 & $\mathrm{~m}$ & & $\mathrm{H}-8, \mathrm{OH}-7$ & H-5, H-8 \\
\hline 7 & 162.9 & $\mathrm{C}$ & & & & H-5, H-8 & \\
\hline 8 & 102.4 & $\mathrm{CH}$ & 6.1 & $\mathrm{~d}$ & 2.0 & OH-7, H-8,H-6 & H-5,H-6 \\
\hline 9 & 157.7 & $\mathrm{C}$ & & & & H-5, H-2, H-8 & \\
\hline 10 & 117.0 & $\mathrm{C}$ & & & & H-6, H-8 & \\
\hline 1 & 123.0 & $\mathrm{C}$ & & & & H-2',H-2,H-5' & \\
\hline 2 & 120.1 & $\mathrm{CH}$ & 6.5 & $\mathrm{~d}$ & 2.0 & $\mathrm{H}-2^{\prime}, \mathrm{H}-4^{\prime}$ & $\mathrm{H}-2, \mathrm{H}-4$ \\
\hline $3^{\prime}$ & 147.8 & $\mathrm{C}$ & & & & $\mathrm{CH}_{3}, \mathrm{H}-2^{\prime}, \mathrm{H}-4^{\prime}$ & \\
\hline $4^{\prime}$ & 116.8 & $\mathrm{CH}$ & 6.3 & $\mathrm{~m}$ & & H-2',H-5' & $\mathrm{CH}_{3}, \mathrm{H}-2$ \\
\hline 5 , & 112.2 & $\mathrm{CH}$ & 6.3 & $\mathrm{~m}$ & & $\mathrm{H}-4$ & $\mathrm{H}-2$ \\
\hline 6 & 146.3 & $\mathrm{C}$ & & & & H-2',H-5' & \\
\hline $\mathrm{OMe}$ & 55.9 & $\mathrm{CH} 3$ & 3.8 & $\mathrm{~s}$ & & $\mathrm{CH}_{3}$ & H-2, H-4 \\
\hline
\end{tabular}




\section{Experimental Section}

Melting point was uncorrected. The IR spectrum was measured on a Necolet IR-2000, ${ }^{1}$ HNMR and ${ }^{13} \mathrm{CNMR}$ spectra were recorded on an ACF-300, DMSO-d6 as solvent and TMS as int. standard. MS was recorded on a Finnigan FTMS-2000.

The dried roots of Smilax glabra were extracted with 95\% EtOH under reflux. After evaporating the solvent, the crude extract was extracted with $\mathrm{Et}_{2} \mathrm{O}$ and EtOAc, respectively to give $30 \mathrm{~g}$ of EtOAc extract. Successive column chromatography using a $\mathrm{CHCl}_{3}-\mathrm{MeOH}$ solvent system with increasing polarity, and repeated column chromatography of series $\left(\mathrm{CHCl}_{3}-\mathrm{MeOH}, 20: 1\right)$ afforded compound $\mathbf{1}$.

Compound 1 is pale yellow crystal, $\mathrm{mp} 250-252^{\circ} \mathrm{C}$. IR $\lambda_{\max } 3420,1640 \mathrm{~cm}^{-1}$. UV (MeOH) $\lambda_{\max } 227,255,290$, $308 \mathrm{~nm}$. EIMS m/z $284\left(\mathrm{M}^{+}\right), 269,253,241,213,148$, 137, 105. For ${ }^{1} \mathrm{HNMR},{ }^{13} \mathrm{CNMR},{ }^{1} \mathrm{H}^{-1} \mathrm{H}$ COSY, COLOC data, see Table 1.
Acknowledgement. We acknowledge with gratitude the financial support of National Natural Science Foundation of China.

\section{References and Notes}

1. Jiangsu New College of Medicine. A Dictionary of Traditional Chinese Drugs, People's Press: Shanghai, 1977; 91-93.

2. Cao, Z. Z.; Yi, Y. J.: Hong, W. Q.; Ling, Y. L. Zhongcaoyao 1993, 24, 234.

3. Cao, Z. Z.: Yi, Y. J.: Yang, D. L. Natural Product $R$ \& $D$ 1994, 6 (2), 33.

4 Cao, Z. Z.: Yi, Y. J.; Cao, Y.; Leng, Z. K. Chin. Chem. Lett. 1995, 6, 587.

5. Yi, Y. J.; Cao, Z. Z.; Yang, W. H.; Hong, W. Q.; Cao, Y.; Leng, Z. K. Yaохие Хиеbao 1995, 30, 718.

Sample Availability: available from MDPI. 